\title{
INDEPENDENSI MEDIA: PRO-KONTRA OBJEKTIVITAS DAN NETRALITAS PEMBERITAAN MEDIA
}

\author{
Musfialdy \\ Program Studi Ilmu Komunikasi Fakultas Dakwah dan Komunikasi \\ UIN Sultan Syarif Kasim Riau \\ Email: musfialdy@uin-suska.ac.id
}

\begin{abstract}
Abstrak
Sejak dahulu sampai sekarang media massa selalu menjadi sorotan masyarakat, terutama adanya peristiwa-peristiwa tertentu. Idealismenya berita yang di bangun oleh suatu media, adalah perwujudan dari realitas yang ada pada peristiwa tersebut. Kenyataannya berita tidak hanya menampilkan realitas yang ada. Isi media yang disampaikan kepada khalayak tidak datang dari "ruang hampa" yang netral, bebas kepentingan, dan disalurkan oleh medium yang bebas distorsi. Berita merupakan hasil pengaruh kebijakan internal organisasi media dan pengaruh eksternal media itu sendiri. Sering kali media senantiasa memilih isu, informasi atau bentuk konten yang lain berdasar standar para pengelolanya. Hal inilah yang menjadikan pemberitaan yang ditampilkan terkadang dianggap berat sebelah dan merugikan sebagian kalangan. Tujuan tulisan ini menganalisa independensi media terutama objektivitas dan netralitas pemberitaan media. Hasil penelitian ini menunjukkan sebuah berita sebagai isi media adalah hasil konstruksi realitas. Media massa mempunyai peluang yang sangat besar untuk mempengaruhi makna dan gambaran yang dihasilkan dari realitas yang dikonstruksinya. Sebuah berita merupakan sebuah konstruksi realitas ditambah ideologi dan kepentingan media itu sendiri. Seharusnya berita dalam media massa diarahkan agar dapat memberikan manfaat nyata bagi masyarakat dan khalayaknya, bukan hanya sekadar untuk membebaskan media massa dan pemiliknya dari kewajiban harapan dan tuntutan masyarakat.
\end{abstract}

Kata Kunci: Independensi media, netralitas media, objektivitas media.

\section{PENDAHULUAN}

Sejak dahulu sampai sekarang media massa selalu menjadi sorotan masyarakat, terutama adanya peristiwa-peristiwa tertentu seperti peristiwa politik (pemilihan umum), peristiwa ekonomi (pameran-pameran dagang), peristiwa budaya (festival budaya) serta peristiwa hukum (berita tentang kasus-kasus pengadilan). Sorotan sebagian masyarakat tentang penilaian (berita) di sebagian media terhadap peristiwa tersebut terkadang tidak objektif dan tidak netral. Pemberitaan di media sudah berpihak kepada suatu kelompok tertentu. Pemberitaan yang ditampilkan terkadang dianggap berat sebelah dan merugikan sebagian kalangan. Di sini dipertanyakan independensi media yang ada. Atau semua media sudah menjadi media partisan.

Pada kasus reuni 212 pada awal bulan Desember 2018 Prabowo Subianto salah satu calon presiden pada pemilu presiden 2018 sempat marah karena banyak media yang tidak meliput acara tersebut. Dalam acara peringatan Hari Disabilitas Internasional di Jakarta, 
Rabu (05/12), awalnya Prabowo mengatakan, "Hampir semua media tidak mau meliput 11 juta lebih orang yang kumpul." Lebih lanjut dikatakannya. "Kebebasan pers itu harus objektif memberi tahu apa adanya,". (BBC Indonesia, 5 Desember 2018) Lebih lanjut Prabowo, tanpa menyebut nama wartawan dan nama media, mengatakan sebagian media mempublikasikan berita bohong. Ia pun mengajak hadirin untuk tidak perlu menghormati wartawan." Boleh kau cetak ke sini dan ke sana. Saya tidak mengakui Anda sebagai jurnalis. Enggak usah saya sarankan kalian hormat sama mereka lagi, mereka hanya anteknya orang yang ingin menghancurkan Republik Indonesia," kata Prabowo, sebagaimana dikutip berbagai media di Indonesia. (BBC Indonesia, 2018).

Pemberitaan Merdeka.com 11 Desember 2018, dikatakan Mantan Danjen Kopassus, rakyat tidak akan percaya kepada media jika menyajikan informasi tak objektif. "Harus ditegur itu (redaksimu). Kau harus tegur jangan tipu rakyat gak baik. Kalau begitu nanti kalian akan ditinggal rakyat. Saya udah gak mau kasih keterangan kepada media yang gak jelas. Karena gak akan disiarkan juga," ujarnya.

Sikap Prabowo tersebut mendapat berbagai tanggap antara lain dari Ketua Aliansi Jurnalistik Indonesia (AJI) Abdul Manan. Menurut Manan Protes yang dituturkan Prabowo itu, kata Manan, adalah hal yang sah-sah saja serta dapat dianggap sebagai kritik terhadap media massa dan wartawan. "Kita proporsional saja, komunitas media menyikapi seruan Prabowo itu dan anggap saja itu sebagai kritik publik terhadap media," ujar Manan (KBR, 2018).

Ketua Dewan Pers Yosep Stanley Adi Prasetyo menegaskan, media tidak bisa diintervensi. Hal tersebut dia katakan dalam acara diskusi publik dalam memperingati Hari Ibu ke-90 'Pers dan Pemajuan Perempuan Indonesia'. "Kita melihat ada yang memberitakan reuni 212 ada yang tidak, kemudian yang pro dengan 212 kesal kepada media tak memberitakan hal tersebut. Itu kebebasan media, mau memberitakan atau tidak," kata Stanley (Merdeka.com, 2018).

Pro kontra keberpihakan media ini pada kasus pemberitaan reuni 212 tersebut merupakan satu di antara ribuan kasus di mana sebagian masyarakat merasa media tidak lagi independen. Tudingan keberpihakkan media kepada suatu kelompok sudah mulai meresahkan masyarakat lainnya. Ketidak-puasan masyarakat akan netralitas media sudah menjadi perhatian bagi kalangan akademisi. Pertanyaan yang timbul di masyarakat seberapa jauh independensi media saat ini. Pertanyaan berikutnya ini berupa:

- Benarkah berita yang menjadi isi media memang benar-benar fakta yang memiliki nilai berita, yang berada di luar campur tangan wartawan ?

- Apakah berita memang cermin realitas ?

- Bagaimana idealismenya peranan media massa?

- Apakah banyak media saat ini sudah menjadi media partisan dimana informasi yang diberitakan oleh mereka sudah berpihak kepada sebagian kelompok atau menguntungkan sebagian kelompok saja?

- Benarkah berita di media benar-benar merupakan realitas objektif yang ditentukan murni oleh standar pemberitaan ? 


\section{ANALISIS DAN PEMBAHASAN \\ Peranan Media Massa}

Sebelum kita membahas mengenai netralnya sebuah berita, pertama kita mengulas tentang media massa sebagai kajian dasar dari berita tersebut. Media massa dalam kehidupan sosial, terutama dalam masyarakat modern telah memainkan peranan yang begitu penting. Menurut McQuail dalam bukunya Mass Communication Theories, ada enam perspektif dalam hal melihat peran media (McQuail, 2000:66) :

- Melihat media massa sebagai window on event and experience. Media dipandang sebagai jendela yang memungkinkan khalayak melihat apa yang sedang terjadi di luar sana. Berita yang ada dalam media merupakan wadah belajar untuk mengetahui berbagai peristiwa.

- Media juga sering dianggap sebagai a mirror of event in society and the world, implying a faithful reflection. Dalam pengertian ini, media merupakan cermin berbagai peristiwa yang ada di masyarakat dan dunia. Media merefleksikan peristiwa apa adanya.

- Memandang media massa sebagai filter, atau gatekeeper yang menyeleksi berbagai hal untuk diberi perhatian atau tidak. Isi media tidak mutlak dari relitas yang ada, tetapi sudah merupakan bentuk yang dibuat dan diseleksi oleh redaksi atau orang orang yang berhubungan dengan media tersebut.

- Media massa sering kali pula dipandang sebagai guide, penunjuk jalan atau interpreter, yang menerjemahkan dan menunjukkan arah atas berbagai ketidak-pastian, atau alternatif yang beragam.

- Melihat media massa sebagai forum untuk mempresentasikan berbagai informasi dan ide-ide kepada khalayak, sehingga memungkin terjadinya tanggapan dan umpan balik.

- Media massa sebagai interlocutor, yang tidak hanya sekadar tempat berlalu lalangnya informasi, tetapi juga partner komunikasi yang memungkinkan terjadinya komunikasi interaktif. (McQuail, 2000).

Mulyana (2001:121) memandang, media massa secara pasti memengaruhi pemikiran dan tindakan khalayak tentang dampak komunikasi massa pada pengetahuan, persepsi, sikap dan perilaku masyarakat Media massa merupakan agen sosialisasi (penyebaran nilai-nilai) memainkan peranan penting dalam transmisi sikap (behaviour), pikiran (cognitive) dan hubungan interaksional.

\section{Objektivitas dan Netralitas media}

Sebagai jendela yang memungkinkan khalayak melihat apa yang sedang terjadi media dituntut untuk objektif. Masyarakat atau audien (pemirsa) menginginkan kebenaran berita yang ditampilkan dan bebas dari distorsi berbagai pihak. Menurut Kovach dan Rosenstiel (2003) dalam Sembilan Elemen Jurnalisme, kewajiban pertama jurnalisme adalah pada kebenaran. Mereka mengatakan bahwa prinsip pertama jurnalisme adalah pengejaran akan kebenaran yang tidak berat sebelah adalah yang paling membedakannya dari semua bentuk 
komunikasi lain. Pada pernyataan tersebut terlihat bahwa jurnalis, tidak peduli dari media mana harus bertumpu pada objektivitas.

Pengertian dari objektivitas dalam dunia media massa adalah suatu metode yang digunakan untuk menghadirkan suatu gambaran dunia yang sedapat mungkin jujur dan cermat dalam batas-batas praktik jurnalistik. Selanjutnya McQuail mengungkapkan, bahwa objektivitas pada umumnya berkaitan dengan berita dan informasi. Menurut McQuail, "Objektivitas bisa jadi hanya merupakan salah satu syarat sebuah berita, namun objektivitas pun memiliki peranan penting sebagai kunci bagi khalayak untuk menilai apakah berita tersebut dapat dipercaya dan reliabel". Perspektif mengenai objektivitas yaitu jurnalis haruslah tidak memihak dalam mengumpulkan, memproses dan memberitakan berita.

Informasi dikatakan objektif jika akurat, jujur, lengkap, sesuai dengan kenyataan, bisa diandalkan dan memisahkan antara fakta dan opini. Informasi juga harus seimbang (netral) dan adil, dalam artian melaporkan perspektif-perspektif alternatif dalam sifat yang tidak sensasional dan tidak bias.

Objektivitas Jurnalistik sering kali merujuk pada keadilan, kenetralan, faktualitas, dan non partisan. Idealismenya berita yang di bangun oleh suatu media, adalah perwujudan dari realitas yang ada pada peristiwa tersebut. Artinya berita di suatu media haruslah netral. Skema yang diajukan Lasswell, misalnya, mengasumsikan media hanya sebagai saluran informasi yang netral, hanya menghubungkan pengirim pesan dan penerima pesan. Berita dibangun dari fenomena-fenomena dan data-data serta analisa yang objektif tanpa ada opini atau subjektif. Realitas yang ditampilkan dalam sebuah berita murni dari hasil yang ada di lapangan.

Netralitas berita dalam sebuah media dipandang karena media hanya merupakan alat atau sarana penyampaian informasi (media as channel). Teori yang memposisikan media as channels adalah The Null Effects Model, yang juga menyatakan isi media bebas dari distorsi. Teori ini menjelaskan bahwa media massa menyampaikan gambaran yang fair tentang realitas dengan meminimalisir distorsi. Keyakinan ini berasal dari asumsi tradisional bahwa ”jurnalis adalah pemancar yang netral".

\section{Berita tidak netral}

Pada kenyataanya berita tidak hanya menampilkan realitas yang ada. Isi media yang disampaikan kepada khalayak tidak datang dari "ruang hampa" yang netral, bebas kepentingan, dan disalurkan oleh medium yang bebas distorsi. Berita merupakan hasil pengaruh kebijakan internal organisasi media dan pengaruh eksternal media itu sendiri. Ada beberapa faktor yang mempengaruhi isi berita di sebuah media:

- Faktor individu, faktor ini berhubungan dengan latar belakang dan profesional dari individu yang mengelola informasi menjadi media.

- Faktor rutinitas, rutinitas media berhubungan dengan mekanisme dan proses penentuan berita.

- Faktor Organisasi, faktor ini berhubungan dengan struktur yang mempengaruhi pemberitaan.

- Faktor ektramedia, faktor ini berhubungan dengan lingkungan yang ada di luar media Orang-orang yang ada di lingkungan media yang mepengaruhi berita: 
1. Sumber berita

2. Sumber penghasilan media

3. Pemerintah dan rekanan media

- Faktor Ideologi

Shoemaker-Reese menegaskan bahwa pengaruh terhadap isi pemberitaan media oleh faktor internal dan eksternal. Pengaruh ini dibagi ke dalam beberapa level, yaitu individu pekerja media (individual level), rutinitas media (media routines level), organisasi media (organizational level), luar media (extramedia level), dan ideologi (ideology level). Level pengaruh tersebut digambarkan melalui lima lingkaran berikut ini :

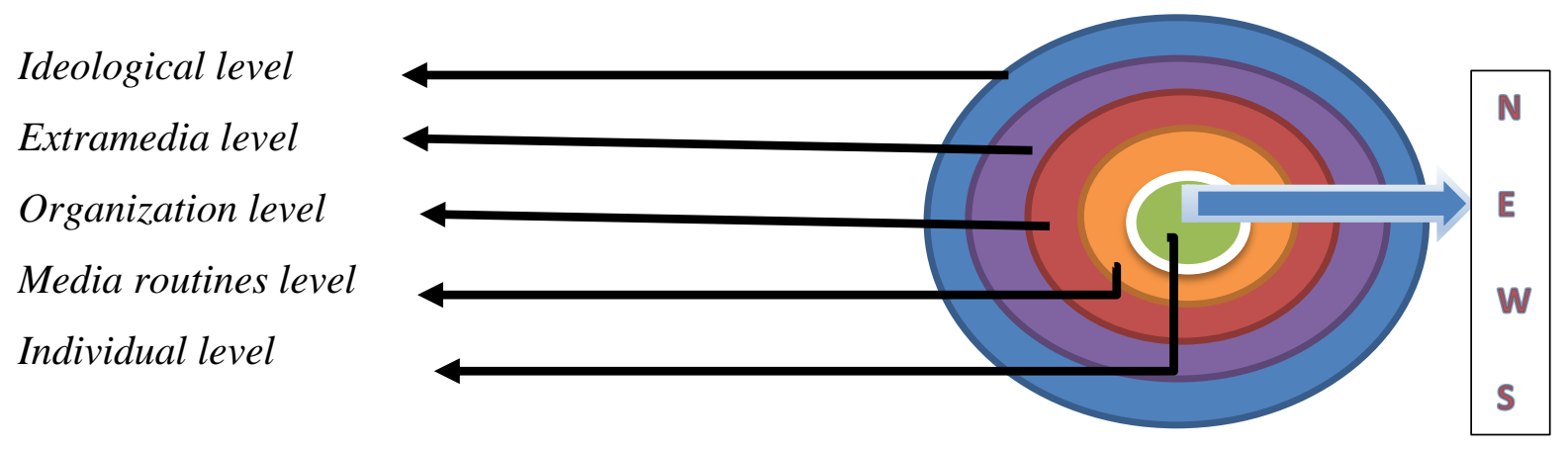

Gambar 1. Lima Lingkaran Pengaruh terhadap Isi Media

Sumber : Pamela J.Shoemaker dan Stephen D. Reese (1996 : p. 60)

\section{Gatekeeper}

Sering kali media senantiasa memilih isu, informasi atau bentuk konten yang lain berdasar standar para pengelola dan pemiliknya (owners). Pemilihan angle, arah dan framing dari isi yang dianggap sebagai cermin realitas tersebut diputuskan oleh para profesional media. Disini khalayak "dipilihkan" oleh media tentang apa-apa yang layak diketahui dan mendapat perhatian. Orang-orang yang menentukan, memilih, menyeleksi yang berperan dalam proses atau mengontrol media disebut getekeper.(Nurudin 2009)

Dalam proses komunikasi massa, gatekeeping dapat diartikan sebagai proses pemilahan, pemilihan, dan penyesuaian informasi yang akan disampaikan kepada audience. Jadi, sebelum suatu informasi disampaikan media kepada audience, informasi tersebut akan mengalami penyaringan terlebih dahulu, dan proses penyaringan atau pemilahan informasi ini akan dilakukan oleh pihak yang dinamakan gatekeeper. Semua media menggunakan gatekeeper dalam proses penerimaan dan penyampaian pesan mereka karena seorang gatekeeper memegang peranan penting dalam proses pemilahan dan pengolahan pesan.

Gatekeeper sendiri merupakan istilah yang digunakan bagi pihak yang melakukan proses gatekeeping. Istilah gatekeeper pertama kali dikenalkan oleh Kurt Lewin, seorang ahli psikologi dari Australia pada tahun 1947, dalam bukunya Human Relations (1947). Fungsi gatekeeper juga adalah untuk mengevaluasi isi media agar sesuai dengan kebutuhan khalayaknya, di mana gatekeeper mempunyai wewenang untuk tidak memuat berita yang dianggap akan meresahkan khalayak. Lebih lanjut lagi, gatekeeper berfungsi sebagai orang yang ikut menambah atau mengurangi, menyederhanakan, dan mengemas agar semua 
informasi yang disebarkan lebih mudah dipahami. (Nurudin, 2009 : 31-32) Selain itu, gatekeeper juga berfungsi untuk menginterpretasikan pesan, menganalisis, menambah data, dan mengurangi pesan-pesan, dimana gatekeeper merupakan pihak yang ikut menentukan pengemasan sebuah pesan dari media massa. Semakin kompleks sistem media yang dimiliki, maka semakin banyak pula proses gatekeeping yang akan dilakukan. Bahkan bisa dikatakan, gatekeeper sangat menentukan kualitas informasi dan dampak dari pesan yang akan disampaikan.

John R. Bittner menjelaskan gatekeeper adalah orang yang berperan penting dalam media massa seperti surat kabar, majalah, televisi, radio, internet, video tape, compact disk, dan buku. Dengan demikian, mereka yang disebut gatekeeper antara lain reporter, editor berita, bahkan editor film atau orang lain dalam media massa yang ikut menentukan arus informasi yang disebarkan. Adapun peranan gatekeeper, yaitu: Seorang gatekeeper dapat menghapus pesan atau bahkan bisa memodifikasi dan menambah pesan yang akan disebarluaskan. Seorang gatekeeper dapat menghentikan sebuah informasi dan tidak membuka "pintu gerbang" (gate) bagi keluarnya informasi yang lain. Dengan demikian, dapat disimpulkan jika paling tidak, gatekeeper mempunyai fungsi sebagai berikut:

1. Menyiarkan informasi

2. Membatasi informasi dengan meng-edit-nya sebelum disebarkan

3. Memperluas kuantitas informasi dengan menambahkan fakta dan pandangan lain

4. Menginterpretasikan informasi.

\section{Media alat kekuasaan}

Dalam perspektif ekonomi politik media, ternyata media tidak bisa netral dan obyektif sebagaimana idealismenya. Media sangat terikat dan dipengaruhi oleh ideologi pemiliknya (owner). Pemilik media ikut serta dalam penetuan angle, arah dan framing dari isi berita yang akan ditampilkan.

Selain pertimbangan ideologi, pertimbangan ekonomis (bisnis) bahkan pertimbangan politik pun ikut serta mewarnai isi berita Maka dari itu, media sangat rentan dijadikan sebagai alat kekuasaan dalam sebuah kepentingan politik. Kepemilikan media menentukan kontrol media, yang pada gilirannya menentukan isi media. Altschull (1984) "hukum kedua dari jurnalisme": "isi media selalu merefleksikan kepentingan mereka yang mendanainya."

Gambaran media yang terikat oleh kepentingan ekonomi dan politik mencerminkan bahwa isi media selalu merefleksikan kepentingan pihak tertentu yang membiayai mereka. Ekonomi politik media menjelaskan dan menekankan perhatian lebih banyak pada struktur ekonomi dan ideologis dari pada muatan isi media itu sendiri

Hal yang dilakukan pemilik media dapat terjadi karena media memiliki kekuatan untuk membentuk opini publik. Upaya tersebut dilakukan melalui agenda setting. Dalam teori agenda setting merupakan teori di mana media memiliki kemampuan untuk menentukan agenda masyarakat melalui berita yang disampaikan olehnya. Adapun kekuasaan media dalam menentukan agenda masyarakat bergantung pada hubungan mereka dengan pusat kekuasaan. Kekuasaan inilah yang menjadi tujuan dari para pemilik mediaKekuatan media mampu memberikan arah ke mana masyarakat harus berpihak dan pilihan-pilihan apa yang harus ditentukan. Dengan kemampuannya, media dapat 
membangun wacana, menggerakkan perubahan keyakinan, dan menggerakkan masyarakat untuk memilih kandidat tertentu.

Dengan kekuatan agenda setting-nya, media juga mempunyai kelebihan untuk menaikkan atau menurunkan elektabilitas seseorang dan partai politik. Kemampuan inilah yang membuat pemilik media melakukan intervensi untuk mengarahkan media-nya dalam membuat pemberitaan yang mendukung partai politik atau kandidat yang diusungnya. Kepentingan pemilik media seperti inilah yang yang terkadang menjadikan media tidak bisa independen dan obyektif sehingga masyarakat juga yang dirugikan dengan opini yang dibuat-buat dengan tujuan tertentu tersebut.

Konsekwensi sebuah perusahaan besar dapat me 'manage', memiliki atau menyebarkan media massa di banyak tempat adalah ideologi yang seragam diberlakukan bagi audience/pembaca. Tidak ada pendekatan spesifik bagi audience di setiap daerah. Pendekatan ekonomi politik, melihat media massa dari siapa penguasa sumber-sumber produksi media massa, siapa pemegang rantai distribusi media massa, siapa yang menciptakan pola konsumsi masyarakat atas media massa dan komoditas lain sebagai efek kerja media. Siapa penguasa sumber-sumber produksi media massa dapat dilihat antara lain dari kepemilikian media massa, kepemilikan rumah produksi penghasil acara-acara televisi

\section{Simpulan}

Sebuah berita sebagai isi media adalah hasil konstruksi realitas. Namun kenyataanya media massa mempunyai peluang yang sangat besar untuk mempengaruhi makna dan gambaran yang dihasilkan dari realitas yang dikonstruksinya. Kebanyakan berita berita yang ada merupakan sebuah konstruksi realitas ditambah ideologi dan kepentingan media tersebut. Sering kali media senantiasa memilih isu, informasi atau bentuk konten yang lain berdasar standar para pengelola dan pemiliknyanya. Pemilihan angle, arah dan framing dari isi yang dianggap sebagai cermin realitas tersebut diputuskan oleh para profesional media (gatekeeper) dan sesuai standar pemiliknya.

Keberpihakkan media dalam memandang sebuah berita, memiliki akibat yang mungkin menguntungkan atau merugikan media. Hal ini berkaitan dengan pihak-pihak berhubungan dan berpengaruh terhadap pemberitaan peristiwa. Karenanya para pengelola media sering merasa tidak "bersalah" jika isi media penuh dengan kekerasan, konflik, pornografi dan berbagai keburukan lain, karena memang menurut mereka faktanya demikian, media hanya sebagai refleksi fakta, terlepas dari suka atau tidak suka.

Seharusnya menurut Denis McQuail, (2000), Kebebasan media massa atau pers harus diarahkan agar dapat memberikan manfaat nyata bagi masyarakat dan khalayaknya, bukan hanya sekadar untuk membebaskan media massa dan pemiliknya dari kewajiban harapan dan tuntutan masyarakat. Begitu juga berita, sebagai isi media harus berita diarahkan agar dapat memberikan manfaat nyata bagi masyarakat dan khalayaknya, bukan hanya sekadar untuk membebaskan media massa dan pemiliknya dari kewajiban harapan dan tuntutan masyarakat. 


\section{Referensi}

Altschull, J. H. (1984). Agents of power: The roles of the news media in human affairs. London: Longman

BBC News Indoenesia. (2018, Desember 5). Prabowo geram kepada media, yang tak meliput Reuni 212 dengan '11 juta orang'. Tersedia di: https://www.bbc.com/indonesia/indonesia-46458924 (Diakses 10 Februari 2019)

KBR. (2018, Desember 6). Seruan Prabowo Tak Hormati Media, Ini Tanggapan Organisasi Jurnalis. Diperoleh dari: https://kbr.id/NASIONAL/12/2018/seruan_prabowo_tak_ hormati_media_ini_tanggapan_organisasi_jurnalis/98384.html_(Diakses 10 Februri 2019)

Kovach, B., Rosenstiel, T. (2006). Sembilan Elemen Jurnalisme. Terj. Yusi A. Pareanom. Jakarta: Yayasan Pantau.

Krisdinanto, N. (2014). Anomali dan Teori Hirarki Pengaruh terhadap Isi Media, 3, 18.

Lewin, K. (1947). Gatekeeping. Diperoleh dari: http://www.utwente.nl/cw/ theorieenoverzicht/Theory\%20clusters/Media,\%20Culture\%20and\%20Society/gatekee ping.doc. (Diakses 10 Februri 2019).

McQuail, D. (2000). Mass Communication Theories, Fourth edition. London: Sage Publication.

McQuail, D. (2002). Mass Communication Theory. Third Edition. London: Sage Publications.

Merdeka.com. (2018, Desember 11). Prabowo Kecam Wartawan, Ketua Dewan Pers Ingatkan 'Media Tidak Bisa Diintervensi. Diperoleh dari: https://www.merdeka.com/peristiwa/prabowo-kecam-wartawan-ketua-dewan-persingatkan-media-tidak-bisa-diintervensi.html (Diakses 10 Februari 2019)

Mulyana, D. (2001). Nuansa-Nuasa Komunikasi; Meneropong Politik dan Budaya Komunikasi Masyarakat Kontemporer. Bandung: Remaja Rosdakarya-Bandung, 2001

Mulyana, D. (2007). Ilmu Komunikasi Suatu Pengantar. Bandung: PT Remaja Rosdakaraya. Nurudin. (2009). Pengantar Komunikasi Massa. Jakarta: Rajawali Pers.

Shoemaker, P.J, Reese, S.D. (1996). Mediating the Message: Theories of Influences on Mass Media Content. USA: Longmann.

Sudibyo, A. (2003). Politik Media dan Pertarungan Wacana. Yogyakarta: LKiS. 